J. Dairy Sci. 92:2625-2633

doi:10.3168/jds.2008-1798

(c) American Dairy Science Association, 2009.

\title{
Effect of different flooring systems on claw conformation of dairy cows
}

\author{
E. Telezhenko, ${ }^{* 1}$ C. Bergsten,${ }^{*} \dagger$ M. Magnusson, $\ddagger$ and C. Nilsson $\ddagger$ \\ *Department of Animal Environment and Health, Swedish University of Agricultural Sciences, PO Box 234, SE-532 23 Skara, Sweden \\ †Swedish Dairy Association, PO Box 234, SE-532 23 Skara, Sweden \\ ‡Department of Rural Buildings and Animal Husbandry, Swedish University of Agricultural Sciences, PO Box 59 , SE-230 53 Alnarp, Sweden
}

\section{ABSTRACT}

The effect of different flooring surfaces in walking and standing areas on claw conformation, claw horn growth, and wear was studied in 2 experiments during 2 consecutive housing seasons in a research dairy herd of 170 cows. In experiment 1 , the flooring systems tested were solid rubber mats, mastic asphalt with and without rubber-matted feed-stalls, and aged concrete slats. In experiment 2 , slatted concrete flooring was compared with slatted rubber flooring. The cows were introduced to the respective flooring systems in early lactation and their claws were trimmed before the exposure period. Toe length, toe angle, sole concavity, and claw width, as well as claw growth and wear rates were recorded for lateral and medial claws of the left hind limb. Claw asymmetry calculations were based on these claw measurements and on differences in sole protrusion between lateral and medial soles. Asphalt floors caused shorter toe length and steeper toe angle. They also increased wear on rear claws $(5.30 \pm 0.31$ and $5.95 \pm 0.33 \mathrm{~mm} /$ mo for lateral and medial claw, respectively; LSM \pm $\mathrm{SE})$ and horn growth rate $(5.12 \pm 0.36$ and $5.83 \pm$ $0.31 \mathrm{~mm} / \mathrm{mo}$ of lateral and medial claws, respectively). Rubber mats instead of asphalt in walking areas reduced wear $(1.36 \pm 0.19$ and $2.02 \pm 0.20 \mathrm{~mm} / \mathrm{mo}$ for lateral and medial claw, respectively) and claw growth $(3.83 \pm 0.23$ and $3.94 \pm 0.17 \mathrm{~mm} / \mathrm{mo}$ for lateral and medial claw, respectively). Rubber-matted feed-stalls together with asphalt walkways decreased claw wear $(3.29 \pm 0.31$ and $4.10 \pm 0.32 \mathrm{~mm} / \mathrm{mo}$ for lateral and medial claw, respectively). The concavity of claw soles was reduced on asphalt, especially in the lateral rear claws. Rubber matting in feed-stalls prevented loss of sole concavity compared with asphalt. Claw asymmetry did not differ between flooring systems. While different access to abrasive flooring affected claw conformation, there was no evidence that flooring system influenced the disproportion between lateral and medial claws.

Received October 9, 2008.

Accepted January 21, 2009.

${ }^{1}$ Corresponding author: evgenij.telezhenko@hmh.slu.se
Key words: claw growth, concrete floor, rubber mat, asphalt floor

\section{INTRODUCTION}

Lameness in dairy cows is an issue for sustainable animal function within the management system and for animal welfare. Claw disorders are believed to be the main cause of lameness and the majority of claw lesions associated with lameness are found on lateral claws of hind limbs (Andersson and Lundström, 1981; Murray et al., 1996). Toussaint Raven (1989) reported that differences in exerted load between lateral and medial claws caused or exaggerated a disproportion of their conformation. Claw shape has been suggested to be an indirect marker of claw health and susceptibility to lameness (Distl et al., 1990). However, debate continues on whether claw shape is a predisposing factor or a result of lesions.

One of the main environmental factors affecting claw conformation is the characteristics of the ground surface (Vermunt and Greenough, 1996). The most commonly used material for walking areas in free-stall systems is concrete. Despite certain positive aspects, such as reasonable price, durability and appropriate hygienic qualities, concrete floors are hard and become slippery over time. Poor concrete quality on walkways is believed to be a main risk factor for lameness, claw lesions, and traumatic injuries (Wierenga and Hopster, 1990; Cook et al., 2004). Other flooring materials, with for example, better traction, are reported to provide better walking surfaces and are now being introduced for traffic areas in free-stall barns. More information is urgently needed on the properties of these new materials and their influence on claw conformation and, in particular, on improving rear claw symmetry.

A few studies have described the effects of rubbercovered walkways in free-stall barns on claw conformation and claw health (Vokey et al., 2001; Vanegas et al., 2006). However, the majority of studies on claw conformation to date only use parameters that characterize the length of the claws, despite the fact that the conformation of the weight-bearing surface seems 


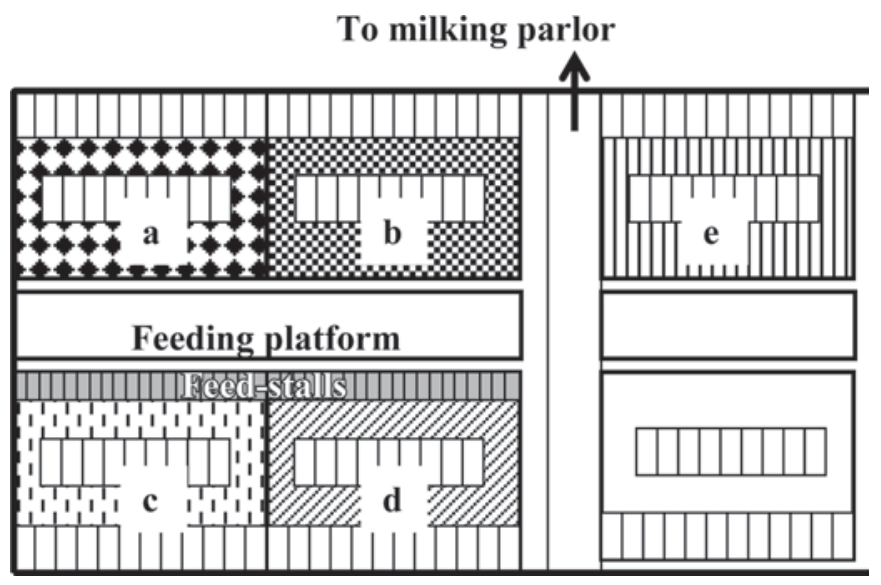

Figure 1. Layout of the experimental part of the barn. The following floorings were used on walking and standing areas, experiment 1: (a) rubber mats (RM), (b) mastic asphalt (MA), (c) rubber mats with feed-stalls (RMF), (d) mastic asphalt with feed-stalls (MAF), (e) slatted concrete (SC). Experiment 2: (a) slatted rubber mats with scrapers (SRMS), (b) slatted rubber mats without scrapers (SRM), (e) slatted concrete (SC).

to be one of the most important conformational traits in relation to claw function. Furthermore, the effect of the ground surface on claw sole conformation has previously only been described in pasture-fed dairy cattle (Tranter and Morris, 1992). Feed-stalls are commonly used for reducing social stress and the consequences of agonistic behavior at the feeding place, but could also improve standing comfort, foot cleanliness, and claw health. DeVries and von Keyserlingk (2006) showed that feed-stalls reduced competition at the manger and improved access to feed, especially in subordinate cows, but to our knowledge, there has been no previous scientific study on the influence of feed-stalls on claw status. The aim of the present study was thus to assess the effect of different flooring systems on conformation, growth, and wear rate of outer and inner rear claws, and their relative asymmetry.

\section{MATERIALS AND METHODS}

\section{Study Herd and Flooring Systems}

The cows used were part of an experimental 170cow dairy herd at the Swedish University of Agricultural Sciences, Alnarp. Use of animals in the study was performed with consent from the local Animal Ethics Committee (Lund, Sweden). The study herd and management are described in detail in Telezhenko et al. (2008). During the studies, 5 sections of the experimental barn were used during experiment 1 and 3 sections during experiment 2, as shown in Figure 1.

The cows were milked twice in a $2 \times 9$ herringbone parlor with automatic cluster removal. The $30-\mathrm{m}$ con- necting walkway from the cubicles to the holding pen and back to the cubicles had older concrete slatted flooring. The 4-mo mandatory grazing period started in the beginning of May and ended in the beginning of September.

Experiment 1. Five different flooring systems were used in experiment 1 (Figure 1): solid floor with rubber mats (RM; KURA-P, Gummiwerk Kraiburg Elastik GmbH, Tittmoning, Germany, www.kraiburg-agri. com); solid floor with acid-resistant, mastic asphalt (MA; polymer bitumen mixed with siliceous ballast, finished with fine rounded sand, produced by BINAB, NCC Roads AB, Stockholm, Sweden); solid floor with rubber mats (KURA-P) and feed-stalls (RMF); solid floor with acid-resistant, mastic asphalt (BINAB) and feed-stalls (MAF); and slatted concrete floor (SC).

Each section had 21 cubicles, with one automatic concentrate feeding station along the outer wall. The feed-stalls (20 per section), which were elevated $17 \mathrm{~cm}$ above the alley, were $0.80 \mathrm{~m}$ wide and $1.60 \mathrm{~m}$ long and were equipped with hard rubber matting (UBO, Barneveld, the Netherlands).

All solid floors were equipped with fully automatic computer-controlled hydraulic manure scrapers with rubber blades and a safety system (DeLaval Delta Master, DM II, DeLaval, Tumba, Sweden). The floors were scraped 11 times per day.

A group of 23 animals from a total of 115 Swedish Holstein cows was allotted to each flooring system. Cows were introduced into the different flooring systems at calving. Since estrus was synchronized, it took approximately 4 mo to complete the groups. At each introduction, cows were stratified by parity (primiparous and multiparous animals) and randomly assigned by lottery to the respective flooring systems. The average number of lactations was 1.8 (1-7 range). The cows were kept on the respective flooring system for an average of $172 \mathrm{~d}$ (75-232 range) after first claw trimming. Cows kept on rubber mats walked a distance of $16 \mathrm{~m}$ on the asphalt floor and $30 \mathrm{~m}$ on the slatted concrete floor 4 times per day (on the way back and forth to the milking parlor). Before entering the experiment, the claws of every cow were trimmed using the same procedure, with the axial portion of the claw sole given a slightly concave shape (Toussaint Raven, 1989).

Experiment 2. In experiment 2, slatted rubber mats (KURA-S, Gummiwerk Kraiburg Elastik GmbH) were used in sections with scrapers (SRMS) and without scrapers (SRM). The same scrapers were used as in experiment 1 (DeLaval Delta Master, DM II), and the floor was scraped 8 times per day. The KURA-S rubber mats had perforated slots $(270 \mathrm{~mm} \times 40 \mathrm{~mm})$ and a void ratio of approximately $20 \%$, but were otherwise identical to the KURA-P mats in experiment 1 . The 
concrete slatted floor (SC) remained without modifications. No section had feed-stalls (Figure 1).

In experiment 2, 63 cows were used: 22 in the section with slatted rubber mats with scrapers, 21 on slatted rubber mats without scrapers and 19 in the section with concrete slatted floors. In contrast to experiment 1 , cows in the section with rubber mats did not walk along the asphalt flooring on the way to milking. The average number of lactations was 2.08 (1-6 range). Cows remained in their respective flooring system for an average period of $174 \mathrm{~d}$ (118-213 range). Claw trimming procedures and conditions for including the cows in the study were identical to those in experiment 1 .

Floor Abrasiveness. To test the abrasiveness of the floor, a method described by Nilsson (1988) was applied. The test body (block of plaster, total weight $2,240 \mathrm{~g}$ ) was dragged over a 10 -m flooring surface at a constant speed of $0.06 \mathrm{~m} / \mathrm{s}$. By weighing the block before and after the drag test, the degree of abrasion was determined. Three measurements were made on each floor type. Mastic asphalt flooring had the greatest abrasion ( $4.48 \pm 0.22 \mathrm{~g}$ per $10 \mathrm{~m}$, mean $\pm \mathrm{SE})$, and rubber mats had the lowest $(0.32 \mathrm{~g}$ per $10 \mathrm{~m})$, while that of concrete slats (measured along the slats) was intermediate $(1.68 \mathrm{~g}$ per $10 \mathrm{~m})$.

\section{Claw Measurements}

Measurements were made on the lateral and medial left hind claws after the first (autumn) trimming and before the second (spring) trimming. Claw measurements were performed in a hydraulic trimming chute by the first author without knowing the system to which the cow belonged. Toe length was measured along the dorsal border from the tip of the toe to the proximal end of the claw capsule at the coronary band, using a vernier caliper. The toe angle was measured at the proximal part of the dorsal border, near the tip of the toe, using a commercial angle finder (Mitsutomo Co., Tokyo, Japan). Claw growth and wear were measured over a 4-mo period by measuring the distal displacement of a mark (2 $\mathrm{mm}$ depth) that had been burnt with a soldering iron into the dorsal wall of the outer and inner claw, $35 \mathrm{~mm}$ from the tip of the toe, at the start of the study. The shape of the claw sole was measured perpendicular to the axis of the metatarsus using a commercial profile gauge (Profilmall 6, Jula, Skara, Sweden) on a lifted foot. The contour of the bearing surface, at its widest point, was reproduced from the profile gauge onto graph paper. The concavity measurement was similar to that described by Tranter and Morris (1992), with some modifications to assess the convex shape of the sole. The depth of the sole was a

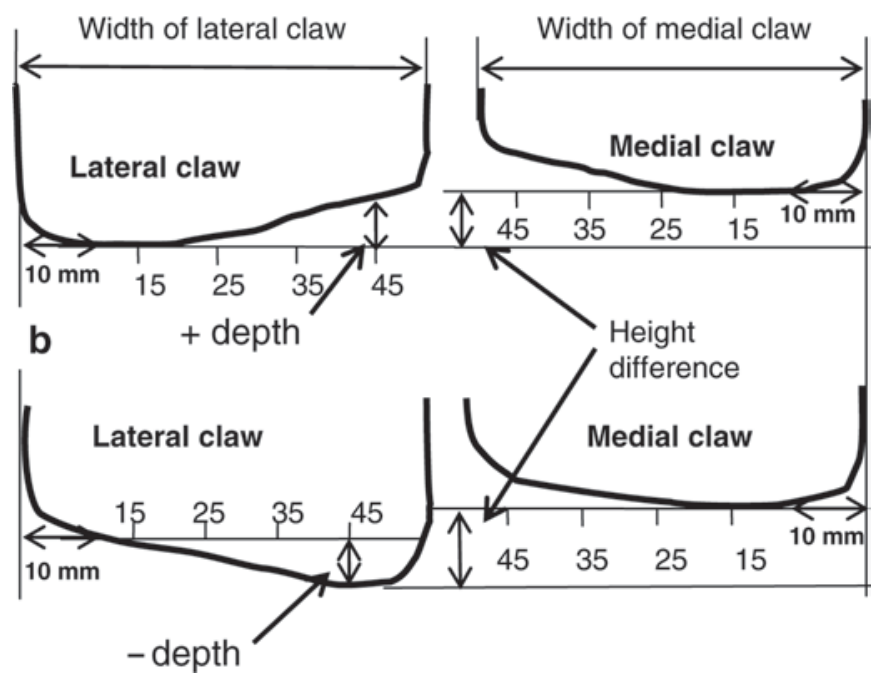

Figure 2. Measurements of sole contour. The depth of the sole (at the widest part) is measured at 15, 25, 35, and $45 \mathrm{~mm}$ from the outer side of the contour of each claw along a horizontal line crossing the contour at $10 \mathrm{~mm}$ perpendicular to a line drawn at the level of the outer side of the claw contour. The contour placed under the horizontal line (b) resulted in negative depth value. Height difference was estimated at 2 distally outmost points of the contour, irrespective of where on the sole this occurred (a), (b).

measured at $15,25,35$, and $45 \mathrm{~mm}$ from the abaxial side of the claw contour of each claw (Figure 2).

Because of difficulties in defining the distal edge of the abaxial wall in some profile contours, all measurements of sole depth were made along a horizontal line crossing the contour at $10 \mathrm{~mm}$ perpendicular to a line drawn at the level of the outer side of the claw contour (Figure 2). The depth values were considered positive if the contour was above the horizontal line, and negative (convex) if the contour was beneath the line. From the sole profile, the width of the lateral and medial claws and the height difference were also obtained (Figure 2 ). Height difference was estimated as the distance from the distally outmost point of the lateral claw to a line drawn at the level of the distally outmost point of the medial claw, perpendicular to the axis of the metatarsus. Other measurements of claw asymmetry were based on difference between the measurements of lateral and medial claws.

\section{Statistical Analysis}

Data were analyzed using the GLM platform of the JMP 5 statistical package (SAS Institute, 2002). In the analysis, sections with rubber flooring were treated as one flooring system within each experiment (RM + $\mathrm{RMF}=\mathrm{RM}$, SRMS $+\mathrm{SRM}=\mathrm{SRM}$ for experiment 1 and 2, respectively). An additional analysis did not 
Table 1. Conformation of claws in the different flooring systems (left hind limb) ${ }^{1}$

\begin{tabular}{|c|c|c|c|c|c|c|}
\hline Flooring system ${ }^{2}$ & \multicolumn{2}{|c|}{ Toe length (mm) } & \multicolumn{2}{|c|}{ Toe angle $\left(^{\circ}\right)$} & \multicolumn{2}{|c|}{ Width of claw (mm) } \\
\hline \multicolumn{7}{|l|}{ Experiment 1} \\
\hline MA & $73.35 \pm 2.33^{\mathrm{b}}$ & $72.54 \pm 1.91^{\mathrm{b}}$ & $50.73 \pm 2.79^{* \mathrm{a}}$ & $55.00 \pm 1.96^{\mathrm{a}}$ & $57.30 \pm 1.68^{* \mathrm{a}}$ & $49.11 \pm 1.60^{\mathrm{a}}$ \\
\hline MAF & $76.25 \pm 2.35^{\mathrm{b}}$ & $75.28 \pm 1.92^{\mathrm{b}}$ & $46.20 \pm 2.81^{* a b}$ & $52.31 \pm 1.98^{\mathrm{ab}}$ & $57.55 \pm 1.72^{* \mathrm{a}}$ & $49.97 \pm 1.64^{\mathrm{a}}$ \\
\hline $\mathrm{RM}$ & $86.47 \pm 2.24^{* \mathrm{a}}$ & $84.27 \pm 1.83^{\mathrm{a}}$ & $40.39 \pm 2.68^{* \mathrm{~b}}$ & $45.70 \pm 1.88^{\mathrm{c}}$ & $55.63 \pm 1.42^{* \mathrm{a}}$ & $50.02 \pm 1.36^{\mathrm{a}}$ \\
\hline SRM & $94.90 \pm 0.85^{* \mathrm{a}}$ & $92.20 \pm 0.78^{\mathrm{a}}$ & $35.79 \pm 1.21^{* \mathrm{a}}$ & $43.81 \pm 0.85^{\mathrm{b}}$ & $54.76 \pm 0.53^{* \mathrm{a}}$ & $50.05 \pm 0.53^{\mathrm{a}}$ \\
\hline
\end{tabular}

${ }^{\mathrm{a}-\mathrm{c}}$ Least squares means within column and within each experiment with different letters differ at $P<0.05$.

${ }^{1}$ Data presented as least squares means $\pm \mathrm{SE}$.

${ }^{2} \mathrm{SC}=$ slatted concrete; $\mathrm{MA}=$ asphalt floor; $\mathrm{MAF}=$ asphalt floor with feed-stalls; $\mathrm{RM}=$ solid rubber floor; SRM $=$ slatted rubber floor.

*Least squares means of lateral claws within same flooring system differ from those of medial claws at $P<0.05$.

demonstrate any considerable effect of feed-stalls or scrapers on claw conformation and rates of growth and wear in sections with rubber mats.

The data from experiments 1 and 2 were analyzed with separate but similar models of claw conformation and claw horn growth/wear rates. The final model for data on claw conformation and claw horn growth/wear rates included the following factors: flooring system (SC, MA, MAF, and RM, df $=3$ for experiment 1 ; $\mathrm{SC}$ and SRM, df $=1$ for experiment 2), month of entry to the flooring system $(\mathrm{df}=3)$, parity $(1,2$, and $\geq 3$, $\mathrm{df}=$ $2)$, and lactation stage $(\mathrm{df}=1)$. The model for analysis of conformational traits included, in addition, a covariance of the measurement after claw trimming $(\mathrm{df}=1)$ as a correction for a baseline. First-order interactions were tested and left in the models if significant.

Because there was no replication of treatment (flooring system) within each experiment, there was a risk of confounding with treatment section (pen). However, because all the sections had equal dimensions and equipment except for the factors studied, the resulting bias was minimized. Although individual animals and their different social interactions in treatment groups could possibly have biased the results in terms of different levels of activity, dividing treatment groups into smaller pens was not possible because of management conditions on the farm. Furthermore, small pens would have dramatically decreased the space for walking activity, which would not be representative to test the effect of flooring system on claw shape under normal conditions for a commercial farm.

Least squares means were calculated from the models and multiple comparisons of treatments were made using a Tukey-Kramer adjustment. The paired $t$-test was used to compare outer and inner claw measurements within a flooring system.

\section{RESULTS}

\section{Claw Conformation}

There were no differences in toe length between different groups at the start of the study. Trimming caused no systematic differences in toe length or toe angle between groups. Lateral claws were trimmed to an average length of $74.13 \pm 0.45 \mathrm{~mm}$ (mean \pm SEM) and a toe angle of $45.46 \pm 0.53^{\circ}$, while the corresponding values for medial claws were $75.17 \pm 0.41 \mathrm{~mm}$ and $47.20 \pm 0.39^{\circ}$.

At the end of the housing period in experiment 1, toe length was significantly shorter in cows from MA and MAF and toe angle was significantly steeper for MA than for RM and SC (Table 1). Neither toe length nor toe angle differed between SC and RM. However, in experiment 2, cows in SRM had significantly longer claws (both lateral and medial) and a shallower toe angle of medial claw than cows in SC (Table 1). There was no statistically significant difference in either lateral or medial claw width across the different flooring systems in any of the experiments.

Pair-wise comparisons within each flooring system revealed that medial claws were significantly steeper and narrower than lateral claws across all flooring systems (Table 1). The toe length of the lateral claw significantly exceeded that of the medial claw for all animals except those in MA and MAF, where the differences were not significant. The differences in measurements between lateral and medial claws (asymmetry) were not significant for any of the flooring systems (Table 2).

\section{Sole Shape}

Sole concavity was initially obtained by dishing the axial part of the sole at trimming and did not differ 

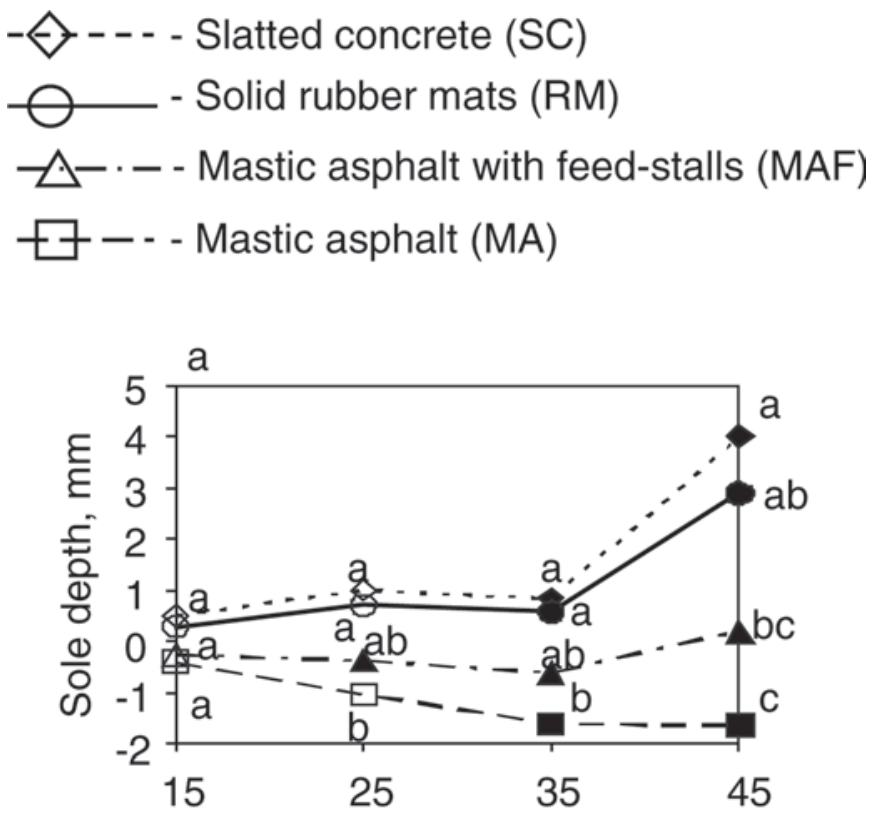

Distance from abaxial edge, $\mathrm{mm}$

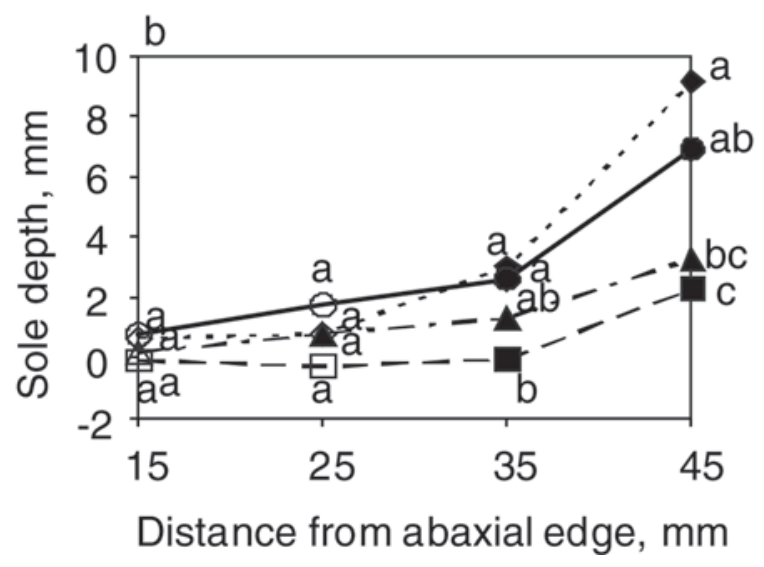

Figure 3. Sole concavity of lateral (a) and medial (b) claws from different flooring systems (experiment 1). Values within the same point with different letters are significantly different $(P<0.05)$. Filled points represent significant differences $(P<0.05)$ between lateral and medial claws within a foot (Paired $t$-test).

significantly among the animals assigned to the different flooring systems before or after the first trimming. The average sole depth after the first trimming at 15 , 25,35 , and $45 \mathrm{~mm}$ from the abaxial margin was 0.15 , $0.74,2.76,6.78 \mathrm{~mm}$ for the lateral claw and 0.52, 2.49, $4.90,11.02 \mathrm{~mm}$ for the medial claw.

Before the second trimming at the end of the housing period in experiment 1 , the sole depth (concavity) of lateral claws had become negative (convex shape) in MA and was significantly different from the positive values at 25,35 , and $45 \mathrm{~mm}$ from the abaxial margin for cows on SC and RM (Figure 3a). The concavity of
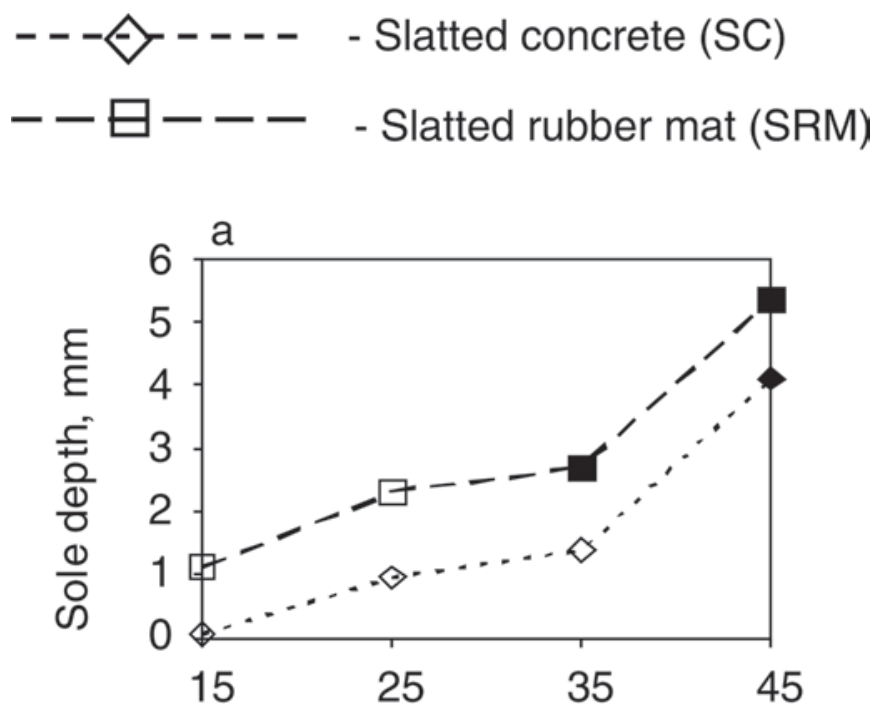

Distance from abaxial edge, $\mathrm{mm}$

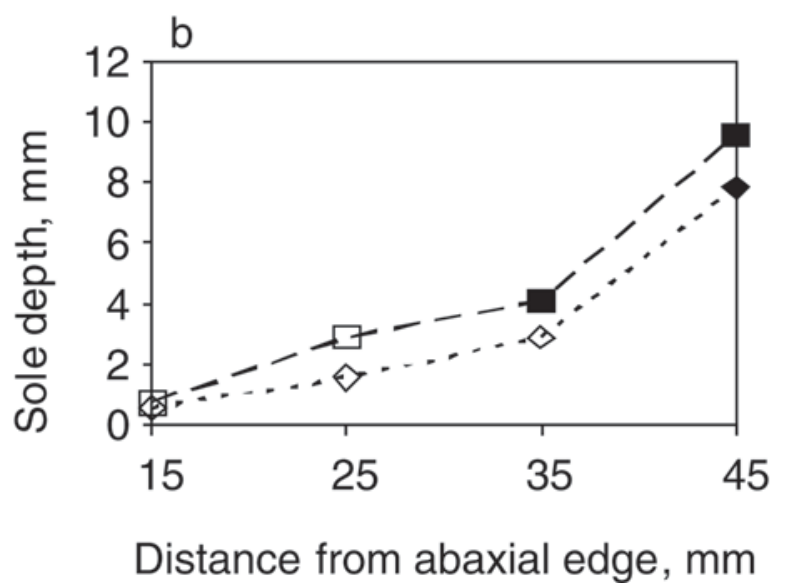

Figure 4. Sole concavity of lateral (a) and medial (b) claws from different flooring systems (experiment 2). No significant differences occurred between the flooring systems. Filled points represent significant differences $(P<0.05)$ between lateral and medial claws within a foot (Paired $t$-test).

lateral claws of cows kept on rubber matting did not differ from that of cows on concrete flooring. The sole depth of lateral claws in MAF was slightly negative at most measuring points but less convex than in MA. The concavity of medial claws was not significantly different across the groups in different flooring systems at 15 and $25 \mathrm{~mm}$ measuring points (Figure 3b). Mastic asphalt resulted in less sole depth than on concrete and rubber floorings at 35 and $45 \mathrm{~mm}$ from the abaxial margin. However, medial claws in MA differed considerably less from other floorings than did the corresponding lateral claws. In medial claws, the concavity was generally greater and significantly different from the concavity in lateral claws at 35 and $45 \mathrm{~mm}$ from the abaxial margin 
Table 2. Claw asymmetry ( $\Delta=$ value of lateral claw minus value of medial claw) in the different flooring systems (left hind limb) ${ }^{1}$

\begin{tabular}{lcccc}
\hline Flooring system $^{2}$ & $\Delta$ toe length $(\mathrm{mm})$ & $\Delta$ toe angle $\left(^{\circ}\right)$ & $\Delta$ claw width $(\mathrm{mm})$ & $\Delta$ sole height $(\mathrm{mm})$ \\
\hline Experiment 1 & & & & $7.13 \pm 2.55$ \\
SC & $5.37 \pm 1.68$ & $-9.58 \pm 3.30$ & $8.19 \pm 2.12$ & $5.70 \pm 1.84$ \\
MA & $2.16 \pm 1.40$ & $-5.50 \pm 3.09$ & $7.58 \pm 2.19$ & $5.66 \pm 1.53$ \\
MAF & $2.44 \pm 1.44$ & $-6.94 \pm 3.17$ & $5.60 \pm 1.81$ & $6.11 \pm 1.58$ \\
RM & $3.69 \pm 1.19$ & $-6.84 \pm 2.62$ & $4.81 \pm 1.67$ & $5.65 \pm 1.30$ \\
Experiment 2 & $3.18 \pm 1.62$ & $-9.36 \pm 2.48$ & $4.70 \pm 0.66$ & $6.56 \pm 1.59$ \\
SC & $2.69 \pm 0.64$ & $-8.02 \pm 1.29$ & $6.73 \pm 0.63$ \\
SRM &
\end{tabular}

${ }^{1}$ Data presented as least squares means \pm SE. No statistical differences between flooring systems.

${ }^{2} \mathrm{SC}=$ slatted concrete; $\mathrm{MA}=$ asphalt floor; $\mathrm{MAF}=$ asphalt floor with feed-stalls; $\mathrm{RM}=$ solid rubber floor; $\mathrm{SRM}=$ slatted rubber floor.

across all flooring systems (Figure 3a, b). Sole depth at $25 \mathrm{~mm}$ was significantly different between medial and lateral claws only in MAF.

The concavity measured at the end of the housing period in experiment 2 tended to be larger in SRM than in SC (Figure 4a, b), but this difference was not statistically significant.

\section{Growth and Wear Rates}

During the 4-mo housing period in experiment 1, the largest claw horn growth of the dorsal wall was recorded in MA (Table 3). Solid floor with rubber mats resulted in the lowest growth rates, but was not significantly different from SC. The greatest abrasion rate of the dorsal wall was found in MA, which differed significantly from the other groups (Table 3 ). Claw wear was significantly reduced in MAF compared with MA. The cows kept in RM had the least wear of the dorsal wall, and only the wear of the medial claw differed significantly from that in SC. The net growth of the dorsal wall was significantly lower in MA and MAF compared with RM and SC.

There were no differences in the rate of toe growth between lateral and medial claws in any of the flooring systems except for MA, for which the growth of the medial claws exceeded that of the lateral claws (Table 3 ). However, MA was the only system for which the wear of the medial claw was not significantly larger than that of the lateral claw. The net growth of the dorsal wall was larger in lateral claws in all flooring systems except for MA.

During the 4 mo of experiment 2, there was no difference in dorsal wall growth rate between SC and SRM (Table 3 ). The wear rates were significantly greater in SC, both for lateral and medial claws. Consequently, net growth was significantly larger in SRM. Pair-wise comparisons revealed significantly higher wear of medial claws in both flooring systems. Net growth tended to be greater in lateral claws $(P=0.07$ and 0.06 for $\mathrm{SC}$ and SRM, respectively). Differences in growth and wear between lateral and medial claws were not statistically significant across the flooring systems (Table 4).

\section{DISCUSSION}

Claw conformation, growth, and wear rates of the claws were greatly affected by access to abrasive flooring in the standing and walking areas. Cows on abrasive asphalt floors had shorter and steeper claws, greater

Table 3. Rates of growth and wear of the dorsal wall of claws of the left hind limb in the different flooring systems $(\mathrm{mm} / \mathrm{mo})^{1}$

\begin{tabular}{|c|c|c|c|c|c|c|}
\hline \multirow[b]{2}{*}{ Flooring system $^{2}$} & \multicolumn{2}{|c|}{ Growth $(\mathrm{mm} / \mathrm{mo})$} & \multicolumn{2}{|c|}{ Wear $(\mathrm{mm} / \mathrm{mo})$} & \multicolumn{2}{|c|}{ Net growth $(\mathrm{mm} / \mathrm{mo})$} \\
\hline & Lateral claw & Medial claw & Lateral claw & Medial claw & Lateral claw & Medial claw \\
\hline \multicolumn{7}{|l|}{ Experiment 1} \\
\hline $\mathrm{SC}$ & $4.09 \pm 0.35^{\mathrm{b}}$ & $4.34 \pm 0.31^{\mathrm{bc}}$ & $1.55 \pm 0.31^{* \mathrm{c}}$ & $2.98 \pm 0.33^{\mathrm{c}}$ & $2.54 \pm 0.37^{* \mathrm{a}}$ & $1.36 \pm 0.32^{\mathrm{b}}$ \\
\hline MA & $5.12 \pm 0.36^{* \mathrm{a}}$ & $5.83 \pm 0.31^{\mathrm{a}}$ & $5.30 \pm 0.31^{\mathrm{a}}$ & $5.95 \pm 0.33^{\mathrm{a}}$ & $-0.18 \pm 0.37^{\mathrm{b}}$ & $-0.12 \pm 0.32^{\mathrm{c}}$ \\
\hline MAF & $4.46 \pm 0.35^{\mathrm{ab}}$ & $4.78 \pm 0.30^{\mathrm{b}}$ & $3.29 \pm 0.31^{* \mathrm{~b}}$ & $4.10 \pm 0.32^{\mathrm{b}}$ & $1.16 \pm 0.26^{* \mathrm{~b}}$ & $0.68 \pm 0.31^{\mathrm{bc}}$ \\
\hline $\mathrm{RM}$ & $3.83 \pm 0.23^{\mathrm{b}}$ & $3.94 \pm 0.17^{\mathrm{c}}$ & $1.36 \pm 0.19^{* \mathrm{c}}$ & $2.02 \pm 0.20^{\mathrm{d}}$ & $2.46 \pm 0.24^{* a}$ & $1.91 \pm 0.24^{\mathrm{a}}$ \\
\hline \multicolumn{7}{|l|}{ Experiment 2} \\
\hline $\mathrm{SC}$ & $4.34 \pm 0.33^{\mathrm{a}}$ & $4.97 \pm 0.37^{\mathrm{a}}$ & $2.22 \pm 0.29^{* a}$ & $3.29 \pm 0.31^{\mathrm{a}}$ & $2.13 \pm 0.31^{\mathrm{b}}$ & $1.67 \pm 0.29^{\mathrm{b}}$ \\
\hline SRM & $4.09 \pm 0.17^{\mathrm{a}}$ & $4.19 \pm 0.20^{\mathrm{a}}$ & $0.98 \pm 0.15^{* \mathrm{~b}}$ & $1.32 \pm 0.16^{\mathrm{b}}$ & $3.11 \pm 0.16^{\mathrm{a}}$ & $2.87 \pm 0.15^{\mathrm{a}}$ \\
\hline
\end{tabular}

${ }^{\mathrm{a}-\mathrm{d}}$ Least squares means within column and within each experiment with different letters differ at $P<0.05$.

${ }^{1}$ Data presented as least squares means $\pm \mathrm{SE}$.

${ }^{2} \mathrm{SC}=$ slatted concrete; $\mathrm{MA}=$ asphalt floor; $\mathrm{MAF}=$ asphalt floor with feed-stalls; $\mathrm{RM}=$ solid rubber floor; $\mathrm{SRM}=$ slatted rubber floor.

* Least squares means of lateral claws within same flooring system differ from those of medial claws at $P<0.05$. 
Table 4. Differences in rates of lateral and medial claw growth, wear and net growth of dorsal wall for the left hind limb in the different flooring systems ${ }^{1}$

\begin{tabular}{lccc}
\hline Flooring system $^{2}$ & $\Delta$ claw growth $(\mathrm{mm})$ & $\Delta$ claw wear $(\mathrm{mm})$ & $\Delta$ net growth $(\mathrm{mm})$ \\
\hline Experiment 1 & $-0.28 \pm 0.31$ & $-1.28 \pm 0.27$ & \\
SC & $-0.70 \pm 0.28$ & $-0.64 \pm 0.24$ & $0.99 \pm 0.29$ \\
MA & $-0.31 \pm 0.28$ & $-0.80 \pm 0.24$ & $-0.06 \pm 0.26$ \\
MAF & $-0.11 \pm 0.20$ & $-0.65 \pm 0.17$ & $0.48 \pm 0.26$ \\
RM & $-0.60 \pm 0.32$ & $-1.01 \pm 0.32$ & $0.54 \pm 0.18$ \\
Experiment 2 & $-0.10 \pm 0.21$ & $-0.34 \pm 0.21$ & $0.40 \pm 0.21$ \\
SC & SRM & & \\
\hline
\end{tabular}

${ }^{1}$ Data presented as least squares means \pm SE. No statistical differences between flooring systems.

${ }^{2} \mathrm{SC}=$ slatted concrete; $\mathrm{MA}=$ asphalt floor; $\mathrm{MAF}$ = asphalt floor with feed-stalls; $\mathrm{RM}=$ solid rubber floor; $\mathrm{SRM}=$ slatted rubber floor.

rates of claw horn growth and wear, lower claw net growth, and smaller claw sole concavity than on less abrasive slatted concrete and rubber mats.

\section{Claw Conformation}

Previous studies on the effect of flooring on claw shape found that the main factor affecting claw conformation was the abrasiveness of the ground (Vermunt and Greenough, 1996; Vokey et al., 2001; Vanegas et al., 2006). Hard floors with higher friction caused large abrasion of the claw horn, especially under wet conditions (Bonser et al., 2003). In the present study, cows exposed to the asphalt floorings (MA and MAF) had significantly shorter and steeper claws than cows exposed to the less abrasive floors (SC and $\mathrm{RM}$ ), while access to rubber-matted feed-stalls in MAF apparently reduced exposure and abrasion of the claw compared with MA. In the present study, the mastic asphalt flooring was chosen to obtain data in comparison to the frequently used concrete flooring. Mastic asphalt flooring is known to give good traction, reduced slippage, and good durability, in contrast to concrete, which becomes slippery, with poor traction over time (Hörndahl, 1995; Telezhenko et al., 2004). The results presented here for asphalt flooring are comparable to those for newly cast concrete flooring with similar abrasion characteristics.

In grazed cows, the sole normally has a concave shape (Tranter and Morris, 1992). In the present study, initial sole concavity was created during claw trimming by shaping the axial part of the sole at the start of the study. Measurements of claw sole profile at the end of housing period showed a remarkable loss of concavity for the claws exposed to the abrasive asphalt floors (MA and MAF). This loss was especially notable in lateral claws exposed to the asphalt floors without feed-stalls (MA), for which the sole profile had a convex appearance. The lack of sole concavity produced by contact with abrasive floors can result in a decreased weightbearing role of the claw wall (Telezhenko et al., 2008).
The exclusion of the claw wall from weight bearing increases the role and load of the digital cushion, the primary function of which is shock absorption (Mülling and Greenough, 2006). When the concavity of the claw sole is lost, the rear mid-sole area comes into contact with the hard floor and overloading of this area may cause trauma of the corium (Toussaint Raven, 1989). Tranter et al. (1993) established an association between lack of sole concavity and increased risk of lameness. On the other hand, the larger contact area of the sole from walking on abrasive floors results in lower contact pressure, which could compensate for the impact of hard floors (Telezhenko et al., 2008).

Sole wear occurring most rapidly along the abaxial margin of the bearing surface of the claw has also been reported in grazing cows exposed to gravel tracks and concrete surfaces (Tranter and Morris, 1992). Greater wear of the abaxial margin of a sole with normal concavity is logical, since this area has most contact with the ground surface. To our surprise, we noted that the abaxial margin continued to wear off on the abrasive flooring, resulting in a convex sole. This could possibly be explained by features of cow locomotion. High speed video recordings of heifers walking on a treadmill show that the lateral claws in hind limbs touch the ground first and make an outward rotation (Meyer et al., 2007).

The concavity of claws on RM with short exposure to asphalt flooring (experiment 1) did not differ from, and was apparently even smaller than, that on SC. However, keeping cows on SRM without any contact with asphalt (experiment 2) resulted in claw profiles with apparently greater concavity than on SC. Thus we suggest that even short contact with an abrasive surface may have an effect on claw sole concavity and, consequently, on the weight-bearing surface of the claw.

\section{Growth and Wear Rates}

The asphalt flooring without feed-stalls resulted in more wear and growth of the claw horn than in the 
other systems. The greatest wear rate on the asphalt floor without feed-stalls was associated with the greatest growth rate of the claw horn. A positive association between claw horn wear and growth has been reported by Vokey et al. (2001), and this can be interpreted as claw growth being affected by wear (Hahn et al., 1986). Vermunt and Greenough (1995) report that in an optimal claw environment, rates of claw horn growth and wear are more or less equal, and the shape is practically unaffected over time. Using feed-stalls with rubber mats in combination with asphalt flooring reduced wear and growth rate of the dorsal claw wall. Therefore, considerable wear of the dorsal wall occurred when the animals were standing and feeding on abrasive floors in front of the feeding platform. Because of the low abrasiveness of SC, this floor did not contribute greatly to claw horn wear. There was almost no difference in claw horn growth and wear between SC and floors with $\mathrm{RM}$ in experiment 1 , when cows on rubber flooring had brief contact with asphalt flooring. In experiment 2, however, cows with slatted rubber mats in the SRM, but without any access to asphalt flooring, had significantly lower wear rates, which resulted in greater net growth and longer claws compared with their herd mates on SC. Therefore, short contact with an abrasive surface can increase claw horn wear and subsequently decrease claw net growth. In cows housed on rubber mats without daily access to abrasive flooring, a considerable amount of weight is carried by the lateral bulb (Telezhenko et al., 2008). A shift of weight bearing toward the posterior part of the claw is usually caused by toe overgrowth due to poor wear on less abrasive flooring. While the loading pattern may be different on a soft floor, the overburdening of the rear part of the claw on a hard surface may cause a contusion of the corium (Bergsten, 2001).

\section{Claw Asymmetry}

There were several differences between lateral and medial hind claws in terms of the parameters studied. The concavity in medial claws was considerably greater than that in lateral claws across all flooring systems tested, which confirms results by Tranter and Morris (1992). There was no significant difference in growth rate between lateral and medial claws for any flooring system except MA, where medial claw had more rapid growth. The medial rear claws showed a higher wear rate of the dorsal wall than the lateral rear claws. The difference in wear rate of the dorsal wall resulted in greater net growth, and consequently greater length of the toe of lateral claws. This finding conflicts with results obtained by Vokey et al. (2001), who found no difference in wear rate between lateral and medial claws, while lateral claws had more rapid growth. These findings lead to 2 different explanations on claw asymmetry regarding claw length: more rapid growth (Vokey et al., 2001) or less efficient wear (our results) of the lateral claw. The significantly steeper toe angle of the medial claw obtained in our study might be a consequence of, or a predisposing factor for, the greater wear rate of the medial claws. Contradictory but consistent results have been obtained by Leach et al. (2005), who found that lateral claws had a steeper angle and a greater wear rate than medial claws.

The outer rear claw is more prone to overgrowth than the medial rear claw (Toussaint Raven, 1989). Hypertrophy of the claw capsule is often explained by increased weight bearing (Ossent et al., 1987; van Amstel et al., 2004). Nuss and Paulus (2006) attributed larger size of lateral claws of the hind feet to larger size of the corium surface and horn capsule, and explained this as an anatomical difference, where lateral claws reach distally further than the medial claws. A possible explanation for claw asymmetry could be a difference in length of the metatarsal bones, where the lateral condyle is longer than the medial (Nacambo et al., 2007). In the present study, the sole of the lateral claw protruded approximately $6 \mathrm{~mm}$ above the sole of the medial claw, and lateral claws were generally longer, wider, and had a shallower angle than medial claws across all flooring systems. The toe length of the lateral claw did not differ significantly from that of the medial claw, when compared within systems with asphalt floors (MA and MAF). Furthermore, when differences between conformational traits of lateral and medial claws were compared across all flooring systems, no effect of flooring was found. The same applied for the difference between rates of growth and wear, which suggests that the different flooring systems did not affect claw asymmetry. Thus, the abrasive floor did not eliminate the disproportion between lateral and medial claws and therefore cannot be a substitute for functional claw trimming.

\section{CONCLUSIONS}

Differences in rear claw conformation were attributed to degree of access to abrasive surfaces. The most intensive access to abrasive floors caused the greatest growth and wear rate, as well as the greatest loss of sole concavity. Less access to abrasive surfaces resulted in well-preserved concavity of the sole and lower growth rate but larger net growth. There was no evidence that flooring system had an effect on asymmetry between lateral and medial claws. Although exposure of claws to very abrasive surfaces may result in zero net growth 
of the claws, it cannot replace regular functional claw trimming.

\section{ACKNOWLEDGMENTS}

This study was funded by the EC framework 5 project 'LAMECOW' (No. QLK5-CT-2002-00969) and by the Swedish Farmers' Foundation for Agricultural Research, which is greatly appreciated. We also thank the following suppliers of material: Gummiwerk KRAIBURG Elastik GmbH for providing the rubber mats; BINAB for providing the mastic asphalt; Willab, for help with the product delivery; De Laval for supplying the scrapers; and Fritz Foderstyrning AB for providing some extra equipment for the experimental barn.

\section{REFERENCES}

Andersson, L., and K. Lundström. 1981. The influence of breed, age, body weight and season on digital diseases and hoof size in dairy cows. Zentralbl. Veterinarmed. Reihe A 28:141-151.

Bergsten, C. 2001. Effects of conformation and management system on hoof and leg diseases and lameness in dairy cows. Vet. Clin. North Am. Food Anim. Pract. 17:1-23.

Bonser, R. H. C., J. W. Farrent, and A. M. Taylor. 2003. Assessing the frictional and abrasion-resisting properties of hooves and claws. Biosystems Eng. 86:253-256.

Cook, N. B., K. V. Nordlund, and G. R. Oetzel. 2004. Environmental influences on claw horn lesions associated with laminitis and subacute ruminal acidosis in dairy cows. J. Dairy Sci. $87(\mathrm{E}$ Suppl.):E36-E46.

DeVries, T. J., and M. A. G. von Keyserlingk. 2006. Feed stalls affect the social and feeding behavior of lactating dairy cows. J. Dairy Sci. 89:3522-3531.

Distl, O., D. S. Koorn, B. T. McDaniel, D. Peterse, R. D. Politiek, and A. Reurink. 1990. Claw traits in cattle breeding programs: Report of the EAAP working group 'claw quality in cattle'. Livest. Prod. Sci. 25:1-15.

Hahn, M. V., B. T. McDaniel, and J. C. Wilk. 1986. Rates of hoof growth and wear in Holstein cattle. J. Dairy Sci. 69:2148-2156.

Hörndahl, T. 1995. Wearing quality and prevention of slipperiness of solid floors in animal houses. Influence of materials and performance. Special report no. 220, Dept. Agricultural Biosystems and Technology, Swedish University of Agricultural Sciences, Lund, Sweden.

Leach, K. A., J. E. Offer, I. Svoboda, and D. N. Logue. 2005. Effects of type of forage fed to dairy heifers: Associations between claw characteristics, clinical lameness, environment and behaviour. Vet. J. 169:427-436.

Meyer, S. W., M. A. Weishaupt, and K. A. Nuss. 2007. Gait pattern of heifers before and after claw trimming: A high-speed cinematographic study on a treadmill. J. Dairy Sci. 90:670-676.
Mülling, C. K. W., and P. R. Greenough. 2006. Functional synergism of the biomechanical systems of the bovine claw. Pages 39-42 in Proc. 14th Int. Symp. Lameness in Ruminants, Colonia del Sacramento, Uruguay.

Murray, R. D., D. Y. Downham, M. J. Clarkson, W. B. Faull, J. W. Hughes, F. J. Manson, J. B. Merritt, W. B. Russell, J. E. Sutherst, and W. R. Ward. 1996. Epidemiology of lameness in dairy cattle: Description and analysis of foot lesions. Vet. Rec. 138:586-591.

Nacambo, S., M. Hässig, C. Lischer, and K. Nuss. 2007. Difference in the length of the medial and lateral metacarpal and metatarsal condyles in calves and cows-A post-mortem study. Anat. Histol. Embryol. 36:408-412.

Nilsson, C. 1988. Floors in animal houses-Technical design with respect to the biological needs of animals in reference to the thermal, friction and abrasive characteristics and the softness of the flooring material. Swedish University of Agricultural Sciences, Department of Farm Buildings, Report 61. Lund, Sweden.

Nuss, K., and N. Paulus. 2006. Measurements of claw dimensions in cows before and after functional trimming: A post-mortem study. Vet. J. 172:284-292.

Ossent, P., D. J. Peterse, and H. C. Schamhardt. 1987. Distribution of load between the lateral and the medial hoof of the bovine hind limb. J. Vet. Med. A. 34:296-300.

SAS Institute. 2002. JMP Statistics and Graphics Guide, Version 5. SAS Inst. Inc., Cary, NC.

Telezhenko, E., C. Bergsten, and M. Magnusson. 2004. Swedish Holsteins' locomotion on five different solid floors. Pages 164166 in Proc. 13th Int. Symp. Lameness in Ruminants, Maribor, Slovenia.

Telezhenko, E., C. Bergsten, M. Magnusson, M. Ventorp, and C. Nilsson. 2008. Effect of different flooring systems on weight and pressure distribution on claws of dairy cows. J. Dairy Sci. 91:1874-1884.

Toussaint Raven, E. 1989. Cattle Footcare and Claw Trimming. Farming Press, Ipswich, UK.

Tranter, W. P., and R. S. Morris. 1992. Hoof growth and wear in pasture-fed dairy cattle. N. Z. Vet. J. 40:89-96.

Tranter, W. P., R. S. Morris, I. R. Dohoo, and N. B. Williamson. 1993. A case-control study of lameness in dairy cows. Prev. Vet. Med. 15:191-203.

van Amstel, S. R., J. K. Shearer, and F. L. Palin. 2004. Moisture content, thickness, and lesions of sole horn associated with thin soles in dairy cattle. J. Dairy Sci. 87:757-763.

Vanegas, J., M. Overton, S. L. Berry, and W. M. Sischo. 2006. Effect of rubber flooring on claw health in lactating dairy cows housed in free-stall barns. J. Dairy Sci. 89:4251-4258.

Vermunt, J. J., and P. R. Greenough. 1995. Structural characteristics of the bovine claw: Horn growth and wear, horn hardness and claw conformation. Br. Vet. J. 151:157-180.

Vermunt, J. J., and P. R. Greenough. 1996. Claw conformation of dairy heifers in two management systems. Br. Vet. J. 152:321-331.

Vokey, F. J., C. L. Guard, H. N. Erb, and D. M. Galton. 2001. Effects of alley and stall surfaces on indices of claw and leg health in dairy cattle housed in a free-stall barn. J. Dairy Sci. 84:2686-2699.

Wierenga, H. K., and H. Hopster. 1990. The significance of cubicles for the behaviour of dairy cows. Appl. Anim. Behav. Sci. 26:309337. 